\title{
Macroeconomic Determinants of Unemployment in Brazil: An ARDL Approach
}

\author{
Fabiano Roberto Santos de Lima1 ${ }^{10}$, Jódiney Benedito Marques² \\ ${ }^{1}$ Estacio de Sa University, Rio de Janeiro, Brazil \\ ${ }^{2}$ Vassouras University, Vassouras, Brazil \\ Email: fabianosdelima@gmail.com,jde_marques@yahoo.com.br
}

How to cite this paper: de Lima, F.R.S and Marques, J.B. (2019) Macroeconomic Determinants of Unemployment in Brazil: An ARDL Approach. Modern Economy, 10, 1744-1758. https://doi.org/10.4236/me.2019.107112

Received: June 11, 2019

Accepted: July 16, 2019

Published: July 19, 2019

Copyright () 2019 by author(s) and Scientific Research Publishing Inc. This work is licensed under the Creative Commons Attribution International License (CC BY 4.0).

http://creativecommons.org/licenses/by/4.0/

(c) (i) Open Access

\begin{abstract}
Brazilian society today faces a serious macroeconomic problem that is the high rate of unemployment. With persistent stagnation of growth, it is concluded that the resumption of jobs will not be something verifiable in the short term, requiring actions that can boost the growth of the product with the improvement of the business environment. The purpose of this paper is to analyze empirically the long-term relationships between aggregate unemployment, monetary policy instruments, exports and direct investments in the country. For this, the econometric strategy used is the approach by ARDL models with causality test developed by Toda and Yamamoto. The results reveal the importance of monetary policy instruments for the job creation environment where percent increases in the level of national activities, inflation and exports lead to reduction of unemployment and also reveal that the direct investments made in the did not contribute to the generation of workplaces. There is evidence that dynamic shocks in the labor market take 4- 7 months to return to equilibrium unemployment levels.
\end{abstract}

\section{Keywords}

Determinants of Unemployment, Unemployment in Brazil, Granger Causality, ARDL Models

\section{Introduction}

High level of unemployment is a problem that affects Brazilian society today. He associated with decrease in disposable income, which turn causes a reduction in aggregate consumption and, depending on the intensity and duration, triggers several others problems in the economy, such as the fall in the domestic product, the increase in welfare expenditures in support of families without income, 
among other social problems.

It is not surprising that unemployment is a central issue in policy discussions and is often used as an indicator for measuring the labor market situation, performance and health of the economy. It is also a sign of success or failure of economic policies implemented by governments, which is evident in Brazil with the poor economic performance achieved in recent years. In the year 2015, for example, real GDP decreased by $-3.8 \%$ compared to the previous year and in 2016 showed a result of $-3.6 \%$. In 2017 , it grew by $1 \%$ and remained the same in 2018. In contrast, unemployment showed a vertiginous increase from the year 2015. Against this backdrop, it is concluded that the resumption of jobs will not be easily verifiable in the short term, if actions are needed that can boost the growth of the product while combining monetary and fiscal policies to favor the business environment.

Inflation is another problem that demands the sacrifice of the population, since the monetary policy instrument that seeks to correct this market distortion ends up generating a tradeoff between inflation and unemployment. Future uncertainties play a fundamental role in this process, since, depending on how expectations are anchored, economic cycles may be amplified [1]. On the other hand, high interest rates practiced in the real market may be interesting to the foreign capital directed to the national business activity, whether through investment in increasing installed capacity, opening new businesses or acquiring companies in the country and, on this point, it can be said that the levels of direct investment in the country have remained, even in the face of economic difficulties.

Exports can be a booster in terms of job creation, given that with low aggregate demand in the domestic market, foreign exchange policies favorable to foreign trade can be a solution for the maintenance of existing jobs or for with the need to increase more manpower resources.

The purpose of this paper is to analyze empirically the long-term relationships between aggregate unemployment, monetary policy instruments, exports and direct investments in the country. The data used cover the period from March 2012 to June 2018. To investigate the relationships among macroeconomic variables, the ARDL model with cointegration test [2] is applied and, in addition, causality is verified with Granger's causality test [3]. This material is composed, in addition to this introduction; this paper is divided into five more sections. The following section presents the empirical literature on unemployment. Section three presents the database and the methodology used in the research. Section four deals with the econometric study and the discussion of the results found. Finally, section five presents the conclusions of the research and, in sequence, the bibliography of the study is presented.

\section{Empirical Literature}

It is possible to find different theoretical approaches that seek to associate unemployment with certain macroeconomic variables. In Brazil the studies that go 
deeper into this singular theme of the labor market are centered in three groups. The first group seeks to improve the concept of unemployment and to specify how it should be operationalized empirically. A second group seeks, from the criteria of segmentation by age, sex, race, level of schooling and regionalization, to determine the structure of the unemployment rate; and finally, a last group studies the aggregate unemployment rate in order to find relations with other macroeconomic variables [4]. Therefore, this work is aligned with the third group.

For the Brazilian case, there is no consensus about which variables are the most indicated, or more assertively, which compose a better set of variables to understand the dynamics of unemployment and, therefore, there is no agreement on which theory best describes [5]-[11]. In Brazil some particularities make the different approaches more propitious to the diversity of results. This is linked to: 1) the approximations and proxies that several authors use when determining the variables most appropriate to the study of unemployment; 2) the problem of the calculation and metrics of the data and 3) due to the econometric method used in the estimations [9]. These possibilities open the door to various models, narratives and results about the "mechanics" of unemployment and its characteristics.

Reference [7] found no statistically significant relationship between inflation and activity level in the Brazilian economy for the 1970s and suggested the estimation of new equations for the Brazilian inflationary process. In his research, he used a model that considered inflation with wage indexation.

A smoothed transition regression model (STR) was used by [12] and revealed that inflationary inertia is relevant to unemployment when analyzed in situations of low inflation uncertainty. The output gap it was only significant when inflationary uncertainty is high. Opposite result was found in [13]. In this case, the output gap was not statistically significant. The authors used nonlinear models of the Phillips curve for forecasting purposes. The controversies are also found in studies using the new keynesian Phillips curve conclude that innovations in the expectation of inflation are transferred to inflation the following month and point to the situation that the increase in inflation does not reduce unemployment [5]. Reference [14] making use of several proxies for the determinants of unemployment in several periods confirmed the effects of unemployment on inflation in the short term and, in addition, indicates positive results on inflation with a devaluation of the exchange rate.

Reference [15] also verified the effects of the transfer of the exchange rate to unemployment in Brazil. The results also point out that movements in real changes contribute to changes in the unemployment rate in the short term. Although there is no consensus, the studies are consistent with economic theory, showing evidence that unemployment is associated with economic activity, validating Okun's law for Brazil [16] [17] [18] [19] [20].

In terms of the role that exports play in generating employment in the country, the perception is that the increase in exports of products is positive because, 
even if they are not recognized as a source of aggregate demand generation [21], with this increase the entire national productive chain benefits, since besides the entry of dollars in the country, there is still the contribution to the reduction of unemployment.

The relationship between direct investment in the country and unemployment is little explored in the literature. Reference [22] analyzed the trajectory of foreign investment in Brazil between 2003 and 2014 and identified that the low performance of the economy as of 2011 was not an obstacle to capital inflows into the country. However, these resources were not directed to the integration of global value chains or to the financing of significant projects in Brazilian infrastructure. The results point to a decrease in the interest in carrying out projects to expand its productive capacity [22], which may have an impact on job creation. Regarding this last statement, reference [23] affirm that there is an illusion in believing that foreign investments in Brazil would increase productive capacity, since, in the period of analysis, idleness would lead the agents to believe there is no reason to the expansion.

In unemployment studies, Autoregressive Distributed Lag (ARDL) models have been found in the international literature [15] [24] [25] [26] [27], and the long-term relationships in Brazil between this variable and its determinants have been little explored [6].

These considerations make the need to identify the dynamics of unemployment and its determinants in Brazil more significant as a result of the changes in the political and economic scenario that occurred in recent years.

\section{Data and Method}

\subsection{Time Series}

This study covers the period from March 2012 to June 2018, a period in which countercyclical efforts related to the subprime crisis of 2008 began to lose strength in the country and shortly afterwards a process of political exhaustion of the current government began, culminating in a serious political-institutional crisis that results in the impeachment of the president of Brazil. From 2012 also, the Brazilian Institute of Geography and Statistics (IBGE) modified the metrics of data calculation of unemployment and, therefore, this investigation starts from this change. Figure 1 shows the evolution of unemployment in the studied period. The data are monthly with application of the logarithmic functional specification in the variables since this modification offers smoothing of variance of the series reducing the problem of heteroskedasticity ${ }^{1}$. The series used follow as described below:

1) Unemployment $(\ln U N)$ - The unemployment rate used is that provided by the IBGE through the national survey for a sample of households (Series 24369 of the website of the Central Bank of Brazil-BCB).

${ }^{1}$ Except for inflation $(I N F L)$ and interest rate $(R A T E)$ that are in their original form. These already have percentage values. This option is also justified by the fact that $I N F L$, in some months of the series, presented negative values. 


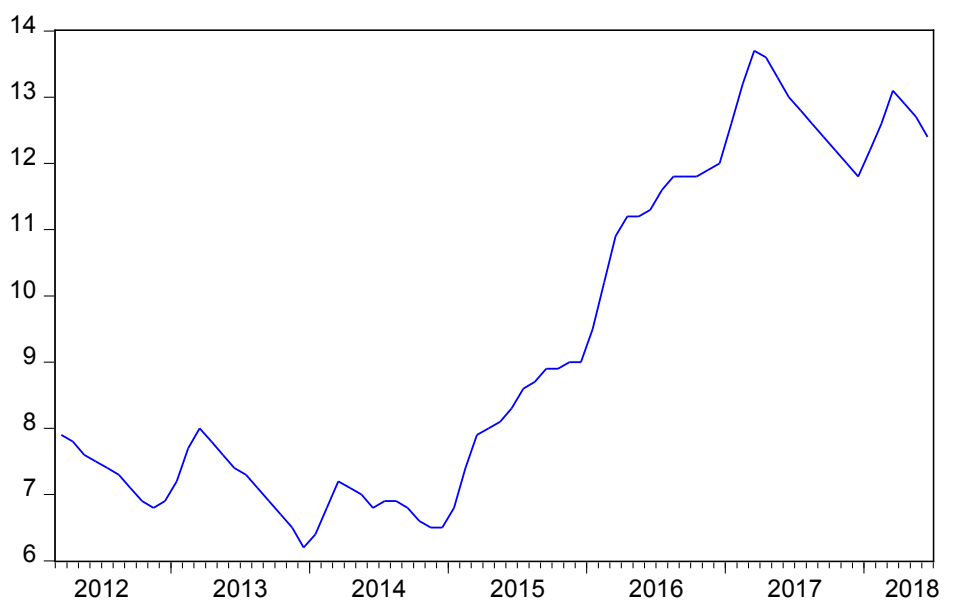

Figure 1. Unemployment in Brazil. Source: Based on data provided by the Brazilian Institute of Geography and Statistics.

2) IBC-Br $(\ln P R O D)$ - The Central Bank of Brazil (IBC-Br) Activity Index with seasonal adjustment is adopted as proxy for GDP. The index incorporates the trajectory of variables considered as proxies for the performance of all sectors of the economy. Available in BCB Series 24364. The trajectory of Brazilian economic activity can be seen in Figure 2.

3) Inflation (INFL) - The broad consumer price index (IPCA) is used as the proxy for national inflation, since the index incorporates the cost of living of households with wages ranging from one to forty minimum wages. BCB Series 433.

4) Interest rate $(\ln R A T E)$ - The rediscount rate defined by the Central Bank (Selic interest rate) accumulated in the month, annualized, serves as a parameter of the interest rate in the country. BCB Series 4189.

5) Exchange rate shocks $(\ln E X C H)$ - The BCB Series 3697 and 3698, dollar values for sale and purchase, respectively are used. The shock in the change was captured from the mean of the results of both series.

6) Direct Investment in the Country $(\ln I N V)$-Direct investment in Brazil is divided into two main instruments: equity participation and intercompany operations. The first considers the inflows of resources in currency or assets related to the acquisition, underwriting or increase of capital stock of companies in the country. The intercompany operations include the granting of credits by subsidiaries or affiliates abroad to their parent companies in Brazil accounted for as investments. The series used is the $22885 \mathrm{BCB}$.

7) Export $(\ln E X P)$-National export data are made available by the Ministry of Foreign Trade and Services (MDIC), compiled from Simplified Export Declarations (DSE) and are reported in kilograms of all monthly records of foreign trade in goods.

\subsection{ARDL Empirical Models of Cointegration}

The bound test [2] is a cointegration test that is based on ARDL models whose 


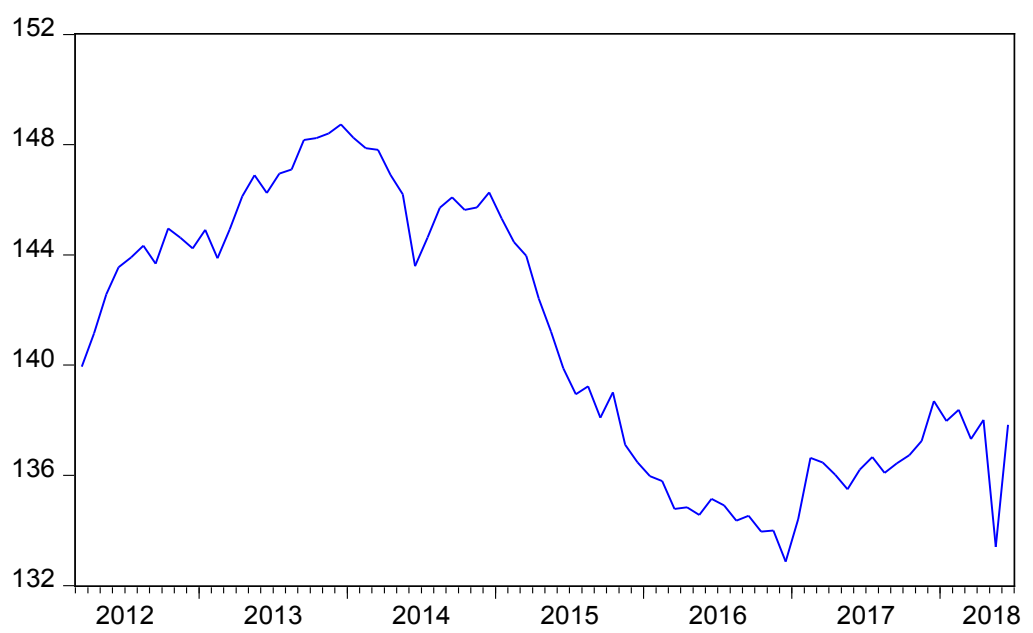

Figure 2. Brazilian Activity Index. Source: Based on data provided by the Central Bank of Brazil.

objective is to verify the existence of a long-term relationship between the variables, and it is not necessary to analyze the order of integration of these variables, since the variables have a minor integration order of what two. Therefore, all series can be integrated of order $0[\mathrm{I}(0)]$, of order $1[\mathrm{I}(1)]$ or mutually cointegrated. It is estimated the cointegration test based on the dynamics of the Error Correction Model (ECM) to confirm the existence of a long-term relationship between the variables of interest using the F-statistic. According to [2], starting from an autoregressive vector of order $p[\operatorname{VAR}(p)]$, one can specify the correction model described in Equation (1):

$$
\Delta Y_{t}=\beta_{0}+\sum_{i=}^{n} \beta_{j} \Delta y_{t-j}+\sum_{i=0}^{n} \delta_{j} \Delta x_{t-j}+\varphi y_{t-1}+\varphi x_{t-1}+\varepsilon_{t}
$$

where $\Delta Y_{t}$ represents the first difference; $\beta_{0}$ is the term of the constant; $\beta_{j}$ and $\delta_{j}$ are the short-run parameters; $\varphi$, represents long-term parameters and $\varepsilon_{t}$ is a white noise process, $\mathrm{N}(0, \sigma 2)$, identically, independently distributed.

The analysis of the relationship between the variables of this study occurs through the estimation of three distinct ARDL models. The model 1 described in Equation (2) suggests the hypothesis that the volume of national economic activity, inflation, interest rate and exchange rate shocks have an influence on the determination of the level of Brazilian unemployment. Equation (3) presents model 2, where it is assumed that product, inflation and direct investments are related to unemployment, and finally, in model 3 , the variables used are product, exchange rate shocks and export are inserted, according to Equation (4).

Model 1

$$
\begin{aligned}
\Delta \ln U N_{t}= & \beta_{0}+\sum_{j=1}^{n} \beta_{j} \Delta \ln U N_{t-j}+\sum_{j=0}^{n} \delta_{j} \Delta \ln P R O D_{t-j}+\sum_{j=0}^{n} \psi_{j} \Delta I N F L_{t-j} \\
& +\sum_{j=0}^{n} \partial_{j} \Delta \ln R A T E_{t-j}+\sum_{j=0}^{n} \tau_{j} \Delta \ln E X C H_{t-j}+\beta_{1} \ln U N_{t-1} \\
& +\beta_{2} \ln P R O D_{t-1}+\beta_{3} I N F L_{t-1}+\beta_{4} \ln R A T E_{t-1}+\beta_{5} \ln E X C H_{t-1}+\varepsilon_{t}
\end{aligned}
$$

Model 2 


$$
\begin{aligned}
\Delta \ln D E S_{t}= & \beta_{0}+\sum_{j=1}^{n} \beta_{j} \Delta \ln U N_{t-j}+\sum_{j=0}^{n} \delta_{j} \Delta \ln \text { PROD }_{t-j}+\sum_{j=0}^{n} \psi_{j} \Delta I N F L_{t-j} \\
& +\sum_{j=0}^{m} \theta_{j} \Delta \ln I N V_{t-j}+\beta_{6} \ln U N_{t-1}+\beta_{7} \ln P R O D_{t-1}+\beta_{8} I N F L_{t-1} \\
& +\beta_{9} \ln I N V_{t-1}+\varepsilon_{t}
\end{aligned}
$$

Model 3

$$
\begin{aligned}
\Delta \ln U N_{t}= & \beta_{0}+\sum_{j=1}^{n} \Delta \ln U N_{t-j}+\sum_{j=0}^{n} \delta_{j} \Delta \ln P R O D_{t-j}+\sum_{j=0}^{n} \psi_{j} \Delta I N F L_{t-j} \\
& +\sum_{j=0}^{n} \tau_{j} \Delta \ln E X C H_{t-j}++\sum_{j=0}^{m} \omega_{j} \Delta \ln E X P_{t-j}+\beta_{11} \ln U N_{t-1} \\
& +\beta_{12} \ln \operatorname{PROD}_{t-1}+\beta_{13} I N F L_{t-1}+\beta_{14} \ln E X C H_{t-1}+\beta_{15} \ln E X P_{t-1}+\varepsilon_{t}
\end{aligned}
$$

\subsection{Unit Root Test}

Aprimary condition for the ARDL cointegration test is that the series used be integrated $\mathrm{I}(0), \mathrm{I}(1)$ or mutually cointegrated. If the series are $\mathrm{I}(2)$ it becomes impossible to use this approach. In order to verify this condition, stationarity tests were performed, according to Enders [28]. The tests performed were the Augmented Dickey-Fuller (ADF) and Phillips-Perron (PP), both with the null hypothesis that series has unit root, this means that its non-stationary. The hypothesis of acceptance of unit root at $10 \%$ of significance is adopted here. The results of the tests are reported in Table 1 and indicate that the variables used in this research are a set of stationary variables, $\mathrm{I}(0)$, and non-stationary variables,

\begin{tabular}{|c|c|c|c|c|c|}
\hline \multirow{2}{*}{ Series } & \multicolumn{2}{|c|}{$\mathrm{ADF}$} & \multicolumn{2}{|c|}{ PP } & \multirow{2}{*}{ Order } \\
\hline & Level & $1^{\text {st }}$ Difference & Level & $1^{\text {st }}$ Difference & \\
\hline \multirow[t]{2}{*}{$\ln U N$} & {$[-3.8899]$} & - & [1.1147] & {$[-3.4960]$} & $\mathrm{I}(1)$ \\
\hline & $(-3.1686)$ & - & $(-1.6139)$ & $(-1.6149)$ & \\
\hline \multirow[t]{2}{*}{$\ln P R O D$} & {$[-0.5049]$} & {$[-9.6764]$} & {$[-2.3498]$} & {$[-9.6900]$} & $\mathrm{I}(1)$ \\
\hline & $(-1.6139)$ & $(-1.6139)$ & $(-3.1624)$ & $(-1.6139)$ & \\
\hline \multirow[t]{2}{*}{$I N F$} & {$[-3.4872]$} & - & {$[-3.5433]$} & - & $\mathrm{I}(0)$ \\
\hline & $(-2.5786)$ & - & $(-2.5786)$ & - & \\
\hline \multirow[t]{2}{*}{$R A T E$} & {$[-2.7472]$} & - & {$[-0.6880]$} & {$[-3.3025]$} & $\mathrm{I}(1)$ \\
\hline & $(-2.5889)$ & - & $(-1.6139)$ & $(-1.6139)$ & \\
\hline \multirow[t]{2}{*}{$\ln E X C H$} & [1.1540] & {$[-5.2833]$} & [1.6275] & {$[-5.1152]$} & $\mathrm{I}(1)$ \\
\hline & $(-1.6139)$ & $(-1.6139)$ & $-(1.6139)$ & $(-1.6139)$ & \\
\hline \multirow[t]{2}{*}{$\ln I N V$} & {$[-7.5418]$} & - & {$[-7.5309]$} & - & $\mathrm{I}(0)$ \\
\hline & $(-2.5882)$ & - & $(-2.5882)$ & - & \\
\hline \multirow[t]{2}{*}{$\ln E X P$} & {$[-5.3670]$} & - & {$[-6.5840]$} & - & $\mathrm{I}(0)$ \\
\hline & $(-3.1639)$ & - & $(-3.1624)$ & - & \\
\hline
\end{tabular}
$\mathrm{I}(1)$. The variables that indicated to be stationary in level were: $I N F L, \ln I N V$ and $\ln E X P$. The other variables were non-stationary in level, but stationary in first difference. They were: $\ln U N$ and $\ln P R O D, R A T E$ and, $\ln E X C H$. No evidence of $\mathrm{I}(2)$ variables was found in the tests.

Table 1. Augmented Dickey-Fuller (ADF) and Phillips-Perron (PP) stationarity test.

Note: [ ] denotes T-statistic values; ( ) denotes the critical value. Source: Author's calculation. 


\subsection{Granger Causality Test of Toda and Yamamoto}

The use of autoregressive models is aimed at finding dynamic relationships between time series of a system, more precisely the response of endogenous variables to shocks in their innovations. The reduced form of VAR can be presented as Equation (5).

$$
y=c+\sum_{i=1}^{k} \Gamma_{i} y_{t-i}+\eta x_{t}+\varepsilon_{t}
$$

where $y_{t}$ is the vector composed of $p$ endogenous variables of the system $y_{t}=\left[y_{1}\right.$, $\left.t, \ldots, y_{p}, t\right], c$ is the vector of constants, $\Gamma_{i}$ is the coefficient matrix of the lags of the endogenous variables, $k$ is the number of lags in the system, $x_{t}$ is the vector of exogenous variables, $\eta$ represents the matrix of exogenous variables and $\varepsilon_{t}$ the error term.

The effects can be measured, starting from a shock in the innovation of the temporal process, through the impulse-response function. The OLS estimation for the autoregressive vector coefficients necessarily need to be stationary and, if any series of the analyzed model presents any unit root, the inference is not valid in the VAR representation. So that do not get caught up in this impediment, [3] propose an approach to the causality test [29] based on a standard VAR model for variable levels, rather than first-order differences. The proposal is to estimate an increased VAR, which guarantees the asymptotic distribution of the Wald statistic.

The test [3] consists: 1$)$ defining the optimal number of lags $(z)$ and the maximum order of integration of the system (e). 2) estimating a level VAR with a total of $(z+e)$ lags. That is, the last lags $(e)$ are discarded (not restricted) in the Wald test. The additional (e) lags enter the system to correct the asymptotic values; 3) apply the Wald restriction test on the first coefficients to test the non-causality hypothesis. The result will show if there is unidirectional causality from $X$ to $Y$ and from $Y$ to $X$ [30].

With this approach, the causality test can be applied to a non-stationary series with the possibility of determining the direction of causality between the analyzed variables. The assumption in this case is that if the maximum order of series integration $\left(d_{\max }\right)$ is added to the Granger model, it can be applied to the non-stationary series level and provide valid estimates [3]. One can specify the proposed one through the bivariate VAR models $\left(z+d_{\max }\right)$ comprised by unemployment and independent variables, according to Equation (6) and Equation (7) below:

$$
\begin{gathered}
X_{t}=\omega+\sum_{i=1}^{m} \theta_{i} X_{t-1}+\sum_{m+1}^{m+d_{\max }} \theta_{i} X_{t-1}+\sum_{i=1}^{m} \delta_{i} Y_{t-1}+\sum_{m+1}^{m+d_{\max }} \delta_{i} Y_{t-1}+v_{1 t} \\
Y_{t}=\psi+\sum_{i=1}^{m} \varphi_{i} Y_{t-1}+\sum_{m+1}^{m+d_{\max }} \varphi_{i} Y_{t-1}+\sum_{i=1}^{m} \beta_{i} X_{t-1} \sum_{m+1}^{m+d_{\max }} \beta_{i} X_{t-1}+v_{2 t}
\end{gathered}
$$

where $X$ is unemployment, $Y$ is the dependent variable. $\omega, \theta, \delta, \psi, \varphi$ and $\beta$ are parameters of the model and $d_{\max }$ is the maximum order of integration that occurs in the system; $v_{1 t} \sim \mathrm{N}\left(0, \Sigma V_{1}\right)$ and $v_{2 \mathrm{t}} \sim \mathrm{N}\left(0, \Sigma V_{2}\right)$ are the residuals of the model and $\Sigma_{1}$ and $\Sigma_{V_{2}}$ are the covariance matrices of $v_{1 t}$ and $v_{2 b}$ respectively. The null hypothesis of non-causality can be expressed as H0: $\delta_{i}=0, \forall_{i}=1$, 
$2, \ldots, m$.

The results in Table 2 indicate that there is a significant precedence relationship of product $(\ln P R O D)$ for unemployment $(\ln U N)$ at a $5 \%$ level of significance. Inflation $(I N F L)$ takes precedence at the level of $1 \%$, while exports $(\ln E X P)$ has a significance of $5 \%$. In general, it can be said that the product, inflation and exports cause the level of unemployment in Brazil.

\section{Estimation of ARDL Models}

The estimates of the models follow the ARDL construction ( $a, b, c, d, e)$, where " $a$ " is defined as the number of lags of the dependent variable, while the others, b, c, d, e, refer to the number of lags of the variables used sequenced. The Adjusted $\mathrm{R}^{2}$ criterion was used for the automatic lag determinations with $\mathrm{Ne}$ wey-West matrix to correct possible correlation effects of the error terms in the constructed regressions. Usually the shocks applied to the macroeconomic variables do not have immediate repercussions on the real economy, so the maximum number of 10 lags for each parameter was used in this study with the order of the variables following the one described previously for each model.

The stability of the regression parameters were verified by the CUSUM and CUSUMSQ tests proposed by [29], both with the purpose to monitor the variability of the process in which the null hypothesis of the test is the stability of the coefficients, calculated to $5 \%$ of significance. The three different models revealed stability in the parameters for the period analyzed, as in Figures 3-5.

\subsection{Long-Term Analysis of Estimated Models}

The verification of the existence of long-term relationship among the variables occurs from the cointegration test. It is possible to verify that, in all the proposed

Table 2. Causality test.

\begin{tabular}{cccc}
\hline Null hyphotesis & Terms of lag $(k+d)$ & Chi $^{2}$ & $P$-value \\
\hline $\ln P R O D$ does not Granger causes $\ln U N$ & $3+1$ & $9.0550^{* *}$ & 0.0286 \\
$\ln U N$ does not Granger causes $\ln P R O D$ & $3+1$ & 5.4605 & 0.1410 \\
$I N F L$ does not Granger causes $\ln U N$ & $6+1$ & $26.2257^{\star * *}$ & 0.0002 \\
$\ln U N$ does not Granger causes $I N F L$ & $6+1$ & 3.2543 & 0.7763 \\
$R A T E$ does not Granger causes $\ln U N$ & $6+1$ & 10.2024 & 0.1164 \\
$\ln U N$ does not Granger causes $R A T E$ & $6+1$ & 5.2491 & 0.5123 \\
$\ln I N V$ does not Granger causes $\ln U N$ & $3+1$ & 4.4030 & 0.2211 \\
$\ln U N$ does not Granger causes $\ln I N V$ & $3+1$ & 3.4898 & 0.3221 \\
$\ln E X P$ does not Granger causes $\ln U N$ & $7+1$ & $16.7315^{\star *}$ & 0.0192 \\
$\ln U N$ does not Granger causes $\ln E X P$ & $7+1$ & $37.2497^{\star * *}$ & 0.0000 \\
$\ln E X C H$ does not Granger causes $\ln U N$ & $3+1$ & 4.4030 & 0.2211 \\
$\ln U N$ does not Granger causes $\ln E X C H$ & $3+1$ & 3.4898 & 0.3221 \\
\hline
\end{tabular}

Note: Indicates ${ }^{\star}$ significant at $10 \% ;{ }^{* *}$ significant at $5 \%$; ${ }^{* *}$ significant at $1 \%$. Source: Author's calculation. 


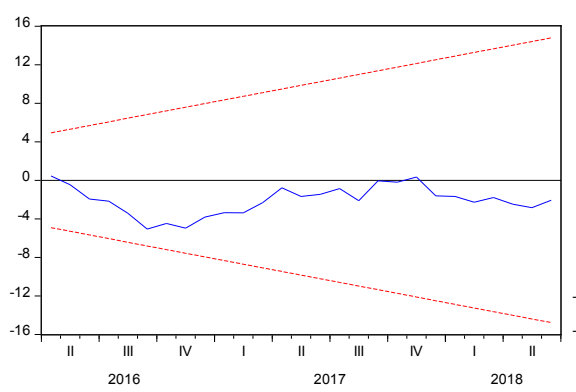

- CUSUM -...- 5\% Significance

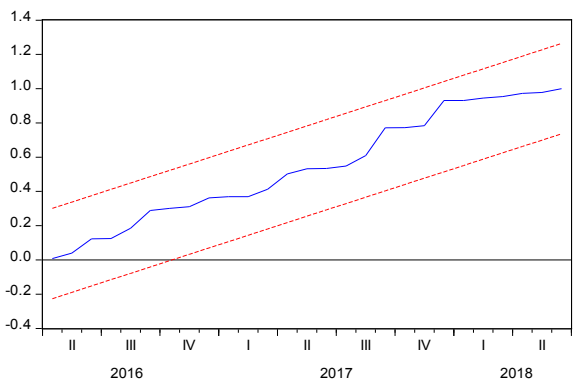

- Cusum of Squares -..-. $5 \%$ Significance

Figure 3. Model 1 Stability Test-CUSUM and CUSUMSQ. Source: Author's computation based on survey data.
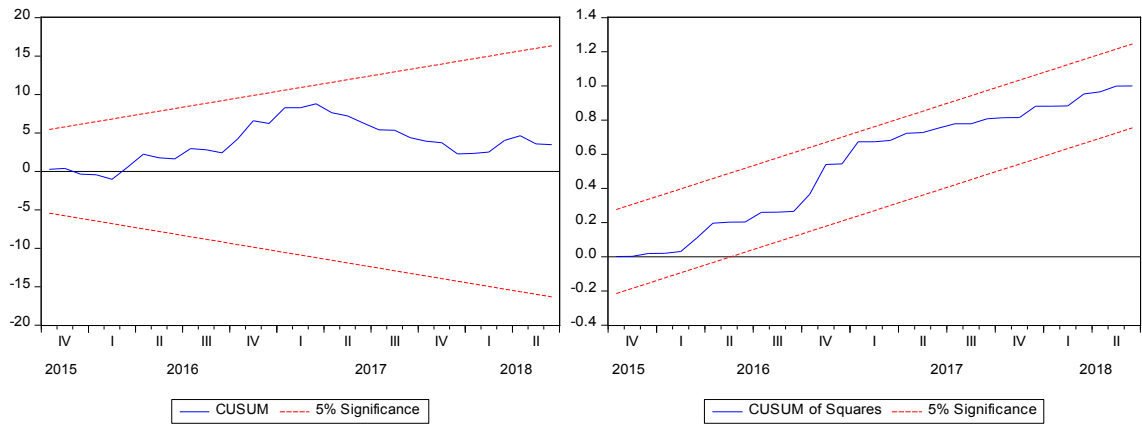

Figure 4. Model 2 Stability Test-CUSUM and CUSUMSQ. Source: Author's computation based on survey data.
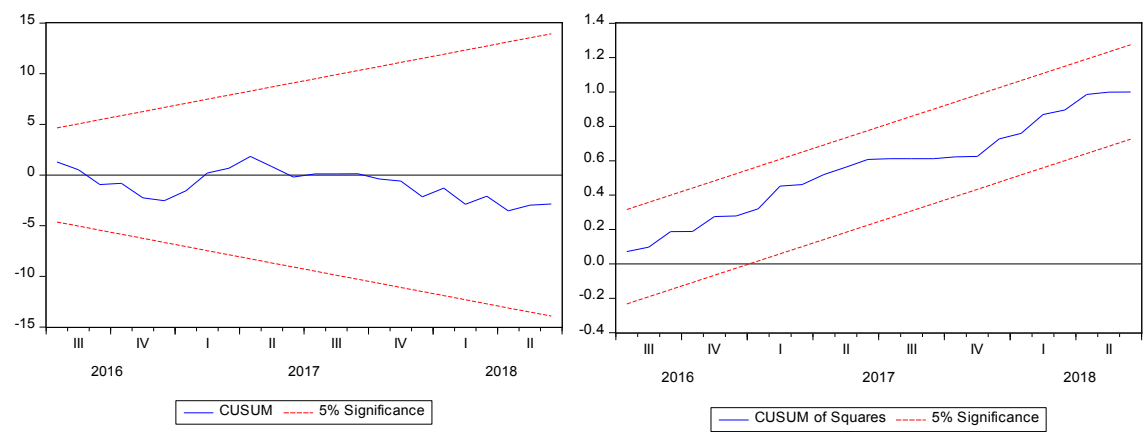

Figure 5. Model 3 Stability Test-CUSUM and CUSUMSQ. Source: Author's computation based on survey data.

models, the results of the cointegration tests indicated that it is possible to have a short or long term relationship between the variables. The F-statistic in all models are above the upper boundaries I(1), thus rejecting the null hypothesis at $1 \%$ that there is no cointegration between the variables, as reported in Table 3.

All models presented adequate residuals, with absence of serial autocorrelation and heteroskedasticity (Table 4). The signs and magnitude of the coefficients of the models are in line with the economic theory of the Phillips curve and Okun's law, suggesting that domestic product and inflation impact negatively on the level of unemployment.

In Table 4 shows the magnitude of the coefficients. It is reported that Model 1 
Table 3. ARDL cointegration test-bound test

\begin{tabular}{cccc}
\hline Parameters & $\begin{array}{c}\text { Model 1 } \\
\text { ARDL (10, 9, 0, 10, 5) }\end{array}$ & $\begin{array}{c}\text { Model 2 } \\
\text { ARDL }(10,5,7,7)\end{array}$ & $\begin{array}{c}\text { Model 3 } \\
\text { ARDL }(10,5,7,5,10)\end{array}$ \\
\hline F-statistic & 13.44 & 7.84 & 7.35 \\
Inferior limit I(0) & 3.74 & 4.29 & 3.74 \\
Superior limit I(1) & 5.06 & 5.61 & 5.06 \\
Selection criteria & $\mathrm{R}^{2}$ Adjusted & $\mathrm{R}^{2}$ Adjusted & $\mathrm{R}^{2}$ Adjusted \\
\hline
\end{tabular}

Source: Author's computation based on survey data.

Table 4. Significance of coefficients and error corretion mechanism- $\ln U N$ dependent variable.

\begin{tabular}{|c|c|c|c|}
\hline \multirow[b]{2}{*}{ Series } & \multicolumn{3}{|c|}{ Estimation of ARDL Models } \\
\hline & $\begin{array}{c}\text { Model 1 } \\
\text { ARDL }(10,9,0,10,5)\end{array}$ & $\begin{array}{c}\text { Model } 2 \\
\text { ARDL }(10,5,7,7)\end{array}$ & $\begin{array}{c}\text { Model 3 } \\
\operatorname{ARDL}(10,5,7,5,10)\end{array}$ \\
\hline $\ln P R O D$ & $-5.9157^{\star * *}$ & $-7.8351^{* * *}$ & $-7.6499 * * *$ \\
\hline INFL & $-0.0790^{* * *}$ & $-0.1935^{*}$ & -0.0607 \\
\hline$R A T E$ & $0.0177^{* * *}$ & - & - \\
\hline $\ln E X C H$ & $0.2945^{* * *}$ & - & $0.5462^{* * *}$ \\
\hline $\ln I N V$ & - & $0.1531^{* *}$ & - \\
\hline $\ln E X P$ & - & - & $-0.6788^{*}$ \\
\hline $\mathrm{R}^{2}$ & 0.9993 & 0.9986 & 0.9994 \\
\hline $\mathrm{R}^{2}$ Adjusted & 0.9984 & 0.9974 & 0.9984 \\
\hline F-statistic & 1104.699 & 790.784 & 1000.312 \\
\hline Prob(F-statistic) & 0.0000 & 0.0000 & 0.0000 \\
\hline Jarque-Bera & 0.8931 & 0.7538 & 0.0931 \\
\hline LM test & 0.0719 & 0.3556 & 0.3695 \\
\hline Heteroskedasticity(BPG) & 0.4404 & 0.6894 & 0.3862 \\
\hline \multicolumn{4}{|c|}{ Short-term Correction Mechanism } \\
\hline CointEq(-1) & $-0.2908^{* * *}$ & $-0.2601^{* * *}$ & $-0.1638^{\star * *}$ \\
\hline
\end{tabular}

Note: Coefficients in bold. Indicates ${ }^{*}$ significant at $10 \%$; ${ }^{*}$ significant at $5 \%$; ${ }^{* *}$ significant at $1 \%$. Source: Author's computation based on survey data.

reveals that the monetary policy instrument affects the level of unemployment, where the increase in interest rate contributes to rise of unemployment in the long term. Same situation when analyzed the exchange rate shock variable, which also positively impacts on unemployment. Model 2 revealed evidence that, in the period analyzed, direct investments in companies in the country were positively related to unemployment.

As opposed to what occurred in the periods prior to the subprime crisis, and why not to say, before the institutional crisis that occurred after the presidential elections in Brazil in 2014, a period in which foreign investments were linked to 
the long-term engagement of companies under the [31], the result presented in this study is aligned with the idea of investments that were not directed at increasing capacity and expanding activities, but aimed at financing working capital or gross fixed capital formation. Investments that were linked to productivity, causing organizations to follow the cycle of unemployment in the country [22] [23].

In Model 3, the signs found were those expected with a statistically significant exchange rate shock at $1 \%$ and positively related to unemployment. The results indicate that increases in the volume of exports contribute to the reduction of the unemployment rate.

\subsection{Short-Term Error Correction Mechanism}

Even with long-term relationships, it is possible that short-term shocks significantly alter these relationships. In this case, in order for the cointegration to continue, a mechanism for correcting these shocks is necessary in order to return to long-term dynamics. In Table 3 it is possible to verify the short-term adjustments that report the estimations of the error correction vectors of the ARDL models.

For all cases, the Error Correction Mechanism presented a negative and statistically significant result. This condition guarantees that there will be convergence of models, indirectly indicating a significant relationship for the long term. The coefficients found were $-0.16,-0.26$ to -0.29 , for each situation analyzed. These results reveal the speed of adjustment in each model for return to initial equilibrium. A result denotes that the unemployment rate takes around 7 months to return to its long-term equilibrium in the first model and approximately 4 months in the other two models.

\section{Conclusions}

This paper aimed to demonstrate empirical evidence of the long-term relationship between unemployment and macroeconomic variables that influence it. Evidence from the causality test indicates that national product, inflation, and exports cause the level of unemployment in Brazil. These results were corroborated with the analysis of the ARDL models of cointegration.

For the long term, the national product, inflation and exports are negatively related to unemployment, indicating that percentage increases in these variables cause a reduction in the level of unemployment. There's evidence that the increase in the interest rate, shocks in the exchange rate and an increase in the direct investments madecontribute to the increase of unemployment in Brazil. In the latter case, the importance of the monetary policy instrument for improving the economic environment and generating job opportunities is revealed. As for direct investments made in Brazil, it can be understood that in the analyzed period, they were not necessarily aimed at expanding productive capacity with more job creation, instead, they may have been directed towards the formation 
of working capital or up to gross fixed capital formation to which, once productivity levels have been reached, a reverse process of downsizing of labor begins. If there are short-term dynamic shocks in which the labor market changes to the level of unemployment, it is possible that the adjustment time to the long-term dynamics takes from 4 to 7 months to return the levels of equilibrium unemployment, depending on the model analyzed.

It is not the purpose of this work to exhaust the debate on the subject, however, it is hoped that it can contribute to the literature since it shows the long-term relationships of unemployment and the determinants that compose it. Knowing their behavior, it is possible to target specific macroeconomic policies combined that can contribute to the resumption of employment levels in Brazil.

\section{Acknowledgements}

The authors thank the unidentified reviewer for the comments made to a preliminary version of the article, exempting him from any responsibility for any remaining errors.

\section{Conflicts of Interest}

The authors declare no conflicts of interest regarding the publication of this paper.

\section{References}

[1] Keynes, J.M. (1936) General Theory of Employment, Interest and Money. Cambridge University Press, Cambridge.

[2] Pesaran, M.H., Shin, Y. and Smith, R. (2001) Bounds Testing Approaches to the Analysis of Level Relationships. Journal of Applied Econometrics, 16, 289-326. https://doi.org/10.1002/jae.616

[3] Toda, H.Y. and Yamamoto, T. (1995) Statistical Inferences in Vector Autoregressions with Possibly Integrated Processes. Journal of Econometrics, 66, 225-250. https://doi.org/10.1016/0304-4076(94)01616-8

[4] Barros, R.P., Camargo, J.M. and Mendonça, R. (1997) Structure of Unemployment in Brazil. Text for Discussion, IPEA, Rio de Janeiro.

[5] Sachsida, A., Schettini, B.P. and Gouvêa, R.R. (2017) Inflation, Unemployment, Exchange Rate Shocks: VAR Estimation for Brazilian Economy. Análise Econômica, 67, 297-322. https://doi.org/10.22456/2176-5456.57948

[6] Triches, D. and Feijó, F. (2017) An Estimation of the Hybrid Phillips Curve for Brazil in the Regime of Inflation Targets. Economia Aplicada, 21, 29-43. https://doi.org/10.11606/1413-8050/ea150953

[7] Lopes, F.L. (1982) Inflation and Activity Level in Brazil: An Econometric Study. Revista Pesquisa e Planejamento Econômico, 3, 639-670.

[8] Zylberstajn, H. and Neto, G. (1999) Theories of Unemployment and Public Employment Policies. Revista de EstudosEconômicos, 29, 129-149.

[9] Sachsida, A. (2013) Inflation, Unemployment and Exchange Rate Shocks: A Literature Review on the Phillips Curve in Brazil. RBE, 67, 549-559.

[10] Proni, M.W. (2014) The Unemployment in the History of Economic Thoughts. Re- 
vista da Abet. Brazilian Journal of Economic Labour Studies, 13, 1-19.

[11] Proni, M.W. (2015) Theories of Unemployment: A Study Guide. Instituto de Economia Unicamp, São Paulo, 256, 1-45.

[12] Areosa, W.D., McAleer, M. and Medeiros, M.C. (2011) Moment-Based Estimation of Smooth Transition Regression Models with Endogenous Variables. Journal of Econometrics, 165, 100-111. https://doi.org/10.1016/j.jeconom.2011.05.009

[13] Arruda, E.F., Oliveira, M.T.A. and Castelar, I. (2017) Recent Dynamics of Brazilian Inflation in Different Environments of Forward-Looking Expectations. Brazilian Journal of Political Economy, 37, 803-831. https://doi.org/10.1590/0101-31572017v37n04a09

[14] Mendonça, M.J., Sachsida, A. and Medrano, L. (2012) Inflation versus Unemployment: New Evidence for Brazil. Economia Aplicada, 16, 475-500. https://doi.org/10.1590/S1413-80502012000300006

[15] Usman, O. and Elsalih, O. (2018) Testing the Effects of Real Exchange Rate Pass-Through to Unemployment in Brazil. Economies, 6, 1-13. https://doi.org/10.3390/economies6030049

[16] Dos Santos, F.S. (2015) Okun's Law and Labour Productivity in Brazil. 43 th National Economic Meeting, Santa Catarina, 8-11 December 2015, 1-15.

[17] Dezordi, L.L. (2011) Okun Law for the Brazilian Economy. Vitrine da Conjuntura, 4, 1-3.

[18] Gouveia, J.M. and Feistel, P.R. (2015) An Application of Okun's Law in Brazil (1996-2013). Revista Economia do Centro-Oeste, 1, 81-90.

[19] Palma and Ferreira, A. and Ferreira, D. (2017) NAIRU, Inflation and Phillips Curve in Brazil: New Evidence from a Time-Variant Model. Estudos Econômicos, 47, 39-63. https://doi.org/10.1590/0101-416147123apd

[20] Medeiros, G.B., Portugal, M.S. and Aragón, E.K.S. (2017) Instability in the New-Keynesian Phillips Curve: An Empirical Study for Brazil. Pesquisa e Planejamento Econômico, 47, 45-76.

[21] Serrano, F. and Melin, L. (2016) Political Aspects of Unemployment: The Neo-Liberal Shift in Brazil. Critica Marxista Online.

[22] Filho, E. (2015) Recent Trajectory of Foreign Direct and Portfolio Investment in Brazil. Boletim de Economia e Política Internacional, 19, 5-20.

[23] Luque, C., Silber, S. and Zagha, R. (2018) Foreign Direct Investment: End of Three Illusions. Boletins de Informações FIPE, January, 56-61.

[24] Mustafa, M. and Rahman, M. (2017) Empirics of the Traditional U.S. Phillips Curve: Evidence from 1930-2016. Journal of Business Strategies, 34, 97-110.

[25] Buba, S. and Aljadi, S. (2017) Inflation and Unemployment in Nigeria: An ARDL Approach. World Journal of Economic and Finance, 32, 69-74.

[26] Şahin, D. (2016) Determinants of Unemployment: Empirical Analysis for China. Akademik Sosyal Araştırmalar Dergisi, 4, 50-58.

[27] Maqbool, M.S., Sattar, T.M. and Bhalli, M.N. (2013) Determinants of Unemployment: Empirical Evidences from Pakistan. Pakistan Economic and Social Review, 51, 191-207.

[28] Enders, W. (2010) Applied Econometric Time Series. John Wiley and Sons Press, New York.

[29] Brown, R.L., Durbin, J. and Evans, J.M. (1975) Techniques for Testing the Constancy of Regression Relationships over Time. Journal of the Royal Statistical Socie- 
ty. Series B (Methodological), 37, 149-192.

https://doi.org/10.1111/j.2517-6161.1975.tb01532.x

[30] Fochezatto, A., Koshiyama, D. and Alencastro, D. (2010) Testing Causal Relations between Foreign Trade and Economic Growth in Latin American Countries: Evidence of Panel Data and Time Series. Revista Economia, 11, 597-629.

[31] Scherer, A.L.F. (1999) The Financial Roots of Foreign Direct Investment Notes on the Recent Brazilian Experience. Ensaios FEE, 20, 81-128. 